\title{
NASA: six weeks to save space station deal
}

Washington. The US Congress has given the National Aeronautics and Space Administration (NASA) six weeks to reach a watertight agreement with Russia that will put the troubled international space station back on schedule - and keep it there.

If NASA fails, say members of two congressional committees, the United States should abandon its collaboration with Russia and build the station only with its original partners, Japan, Canada and Europe.

The impasse results from the Russian government's failure to provide the funds needed to enable a contractor there to build the service module, the main Russian contribution to the station. US observers feel that Russia is dragging its feet in the hope of extracting more financial support from the United States.

"We may have to show that we are prepared to build it ourselves in order to get through to them and get them to stop testing us," Lori Garver, director of the National Space Society, said last week in testimony before a Senate subcommittee.

$\mathrm{Al}$ Gore, the US vice president, wrote to Victor Chernomyrdin, the prime minister of Russia, last month asking for assurances that funding would be made available. Gore asked for a response in time for last week's hearings. But nothing arrived, only adding fuel to congressional concern about the viability of the partnership.

At separate hearings last week of the space subcommittee of the House of Representatives Science Committee, and of the science, space, and technology subcommittee of the Senate Commerce, Science and Transportation Committee, Dan Goldin, the administrator of NASA, promised to resolve the problem within six weeks.
"If it goes beyond a month or so, we [will] begin to lose the ability to hold the schedule for the service module," he told the Senate subcommittee. "One month, maybe six weeks - no longer," he pledged.

Expanding on this before the House subcommittee two days later, Goldin said that the agreement would include "specific milestones" at three or four stages in the module programme to avoid a repetition of the situation. If an agreement was not forthcoming within six weeks, "we'll look at our contingencies and, at an appropriate time, act on them", said Goldin.

The Russian parliament has appropriated the money needed to build the service module, say Congressional staff. But this does not compel the finance ministry to release the money, and the contractor building the module is still not being paid. The issue is now being pursued by Thomas Pickering, the US ambassador in Moscow, and Goldin expressed confidence that it will be resolved.

But several members of Congress remain sceptical about any assurances provided by Russia. One is James Sensenbrenner (Republican, Wisconsin), chair of the House subcommittee, who went to Moscow in January and received what he considered a clear pledge from Oleg Soskovets, Russia's deputy prime minister, that the service module would be funded.

"That was January and this is March and they haven't done it," says Sensenbrenner. "I think I was misled by them. I feel very bitter about it - this administration is going to have to be much more hard-nosed."

Sensenbrenner is sufficiently upset to begin mentioning the unmentionable: a supplementary budget request this year, over and above the $\$ 2.1$ billion the space station

\section{Planet Earth funds revolve into 1996}

Washington. The US National Aeronautics and Space Administration (NASA) has come under fire for carrying over $\$ 650$ million of the funding for its Mission to Planet Earth - one-third of the programme's annual budget - from the 1995 financial year (which ended on 30 September) to 1996.

James Sensenbrenner (Republican, Wisconsin), chair of the space subcommittee of the House of Representatives Science Committee, said last week that the amount of money carried over was "unheard of" and called it "a slush fund". He said that he would be asking the General Accounting Office, which reported the space agency's move, for a full and complete investigation.

According to Dan Goldin, the administrator of NASA, the money has built up because managers have been reluctant to spend money in times of budget uncertainty. Goldin told Sensenbrenner at a Congressional hearing (see above) that he was "as concerned as you are" about the size of the carry-over.

The embarrassing accumulation of Mission to Planet Earth funds is likely to encourage critics of the programme, such as Robert Walker (Republican, Pennsylvania), chair of the House Science Committee, to push for even sharper cuts in its budget this year.

But the mission again received a ringing endorsement from Senator Larry Pressler (Republican, South Dakota), chair of the Senate Commerce, Science and Transportation Committee, who said that it was NASA's “most important and most relevant programme". $\quad$ C. $\mathbf{M}$. is already due to receive, to enable the United States to build the service module itself in time for its April 1998 launch.

It has been estimated that the United States is saving $\$ 2$ billion on the total cost of the space station through its partnership with Russia. But Sensenbrenner says that this number is inaccurate, and that the United States could drop its agreement with Russia at a much lower cost.

The module would cost $\$ 500$ million to build, and additional funds to launch. But Goldin says that the United States would be entitled to recover $\$ 300$ to $\$ 400$ million from Russia if it breaks off collaboration, sufficient to cover some of these costs.

NASA is likely to come under strong pressure to find any extra money from within its existing budget. But if this happened, as Sensenbrenner puts it, there would be "no science money left" at the space agency. Some Republicans would like some of the money to come from NASA's Mission to Planet Earth (see box, below).

Some of the criticism of the US-Russian collaboration is clearly political. Sensenbrenner, for example, has never liked the agreement, and Republicans are generally critical of what they see as the Clinton administration's "softness" in its dealings with Russia.

But concern goes much wider than party politics. Some supporters of the station would like the United States to break with Russia now, allowing the programme to be reconfigured in time for the planned commencement of hardware launches late next year. Such a move would also allow the current Congress, which may turn out to be more Republican - and therefore more supportive of the space station - than the next one, to appropriate the money needed.

Yet politics is likely to rule out such a clear-cut outcome. President Bill Clinton will probably await the results of the Russian presidential election in June, and the attitude of any new administration, before taking any precipitous action. Clinton himself will be keen to play down any problems with Russia in the run-up to his own election in November.

Congress sees the issue differently. Republican staff members say Russia has to understand that, if the service module runs late, it will be easier for Clinton to raise extra money from Congress to build it in the United States than to support a continued US-Russian partnership.

Meanwhile, opponents of the entire programme wait in the wings. "We've had eight designs already, and now it seems to me we're going to get a ninth," says Tim Roemer (Democrat, Indiana). "You will have some very tough questions to answer before the Congress if this agreement falls apart," he told Goldin.

Colin Macilwain 